\title{
KINERJA PENETAPAN PERATURAN DAERAH PADA TAHUN 20I5-20I7 DI DPRD KOTA PALANGKARAYA
}

\section{Performance of the Establishment of Regional Regulations for the Year 20 I5-20I7 in the DPRD of Palangka Raya City}

\section{Raden Biroum \\ Bernardianto * \\ Vina Panduwinata}

Universitas Muhammadiyah

Palangkaraya, Palangka Raya,

Central Kalimantan, Indonesia

email: a_biem@gmail.com

\section{Kata Kunci:}

Kinerja

Peraturan Daerah

\section{Keywords:}

Performance

Local regulations

\section{Accepted}

June 2018

Published

October 2018

\begin{abstract}
Abstrak
Tujuan penelitian ini adalah untuk mendeskripsikan dan menganalisis kinerja DPRD Kota Palangka Raya dalam melaksanakan kekuasaan legislasi serta untuk mendeskripsikan dan menganalisis kendala-kendala yang mempengaruhi DPRD Kota Palangka Raya dalam menetapkan Peraturan Daerah. Penelitian ini menggunakan metode penelitian kualitatif deskriptif. Jenis dan sumber data yang dipilih peneliti adalah data primer dan data sekunder. Teknik pengumpulan data yang digunakan untuk mendapatkan informasi adalah wawancara dan dokumentasi.

Hasil penelitian menunjukkan bahwa kinerja Dewan Perwakilan Rakyat (DPRD) Kota Palangka Raya dalam melaksanakan kekuasaan legislasi bersama pemerintah Kota Palangka Raya dapat dikatakan cukup baik. Pada periode tahun 2015 sampai dengan tahun 2017 telah membahas dan menetapkan 36 Peraturan Daerah. Akan tetapi apabila ditinjau dari inisiasi usulan maka dapat dikatakan kurang memuaskan, karena hanya 9 Peraturan Daerah saja yang merupakan inisiatif DPRD Kota Palangka Raya. Faktor-faktor yang mempengaruhi kinerja DPRD Kota Palangka Raya dalam menetapkan Peraturan Daerah adalah : Sumber Daya Manusia, Data dan Informasi, serta Pengalaman. Keadaan Sumber Daya Manusia yang rata-rata berpendidikan Sarjana ke atas (2I dari 30 orang) sebenarnya merupakan faktor pendukung kinerja. Menilik bahwa basic pendidikan yang tidak sejalan dan pengalaman yang masih kurang turut menjadi kendala untuk mendukung kinerja legislasi anggota DPRD Kota Palangka Raya.
\end{abstract}

\begin{abstract}
The purpose of this study was to describe and analyze the performance of the Regional Parliament of Palangka Raya in carrying out legislative powers and to describe and analyze the constraints that affect the Palangka Raya City DPRD in setting regional regulations. This study uses descriptive qualitative research methods. The types and sources of data chosen by researchers are primary data and secondary data. Data collection techniques used to obtain information are interviews and documentation.

The results of the study show that the performance of the Palangka Raya City DPRD (DPRD) in exercising legislative power with the City of Palangka Raya government is quite good. In the period 2015 to 2017, 36 local regulations have been discussed and established. However, if it is reviewed from the proposal initiation, it can be said to be unsatisfactory, because only 9 Regional Regulations are the initiative of the Palangka Raya City DPRD. Factors that influence the performance of the DPRD of Palangka Raya City in setting regional regulations are: Human Resources, Data and Information, and Experience. The condition of Human Resources with an average Bachelor level education (21 out of 30 people) is actually a supporting factor for performance. Given that the basic education is not in line and experience that is still lacking, it becomes an obstacle to support the legislative performance of members of the Palangka Raya City DPRD.
\end{abstract}

\section{PENDAHULUAN}

Otonomi Daerah adalah hak, wewenang dan kewajiban daerah otonom untuk mengatur dan mengurus sendiri urusan pemerintah dan kepentingan masyarakat setempat sesuai dengan peraturan perundangundangan.
Pengertian ini memberikan implikasi bahwa Pemerintah

Pusat memberika kewenangan seluas-luasnya kepada daerah untuk mengatur rumah tangganya sendiri. Daerah dengan inisiatifnya sendiri dapat menyelenggarakan Pemerintaha Daerah dengan membuat peraturan-peraturan daerah. 
Sebagai lembaga politik, anggota DPRD tidak hanya mampu menyerap dan menyalurkan aspirasi masyarakat melainkan juga hendaknya dapat membantu memfasilitasi penanganan berbagai konflik yang terjadi agar tidak meluas kearah yang tidak diinginkan. Untuk itu lembaga legislatif dan eksekutif harus memiliki kapasitas dan kemampuan manajemen memadai, untuk meningkatkan peran serta masyarakat dalam proses pembangunan perdamaian sesuai dengan UndangUndang yang berlaku.

DPRD berdasarkan UU No. 22 tahun 2003 tentang Susunan dan Kedudukan MPR/DPR/D/DPD dan UU No. 32 tahun 2004 tentang Pemerintahan Daerah telah mendapatkan mandat kekuasaan membuat Peraturan Daerah. Hal ini sejalan terlihat pada isi Pasal 77 tentang Fungsi DPRD yaitu DPRD Kabupaten/Kota mempunyai fungsi a. Legislasi; b. Anggaran; dan c. Pengawasan. Sedangkan pasal 78 mengatur tentang tugas dan wewenang DPRD, DPRD Kabupaten/Kota mempunyai tugas dan wewenang, salah satunya adalah membentuk Peraturan Daerah (Perda) yang dibahas dengan bupati/walikota untuk mendapat persetujuan bersama.

Pemerintahahan Daerah Kota Palangka Raya telah menetapkan beberapa peraturan daerah di era otonomi ini. Berdasarkan pengalaman dan pengamatan penulis, selama ini DPRD Kota Palangka Raya telah berhasil menetapkan beberapa peraturan daerah yang sebagian besar merupakan Perda inisiasi Pemerintah Kota Palangka Raya, sedangkan yang merupakan inisiasi DPRD Kota Palangka Raya minim sekali. Pergeseran kekuasan legislasi di daerah dari eksekutif kepada legislative tersebut belum disertai dengan peningkatan produktifitas DPRD dalam memproduk Perda yang berasal dari inisiatif DPRD. Fenomena yang terjadi bahwasannya Perda Kota Palangka Raya masih tetap lebih banyak berasal dari eksekutif dari pada legislatif tidak menggambarkan urgensi pergeseran tersebut, tidak dibarengi dengan peningkatan baik kualitas maupun kuantitas peraturan daerah dari inisiatif DPRD Kota Palangka Raya.

\section{METODOLOGI}

Penelitian ini merupakan jenis penelitian deskriptif, untuk mengumpulkan informasi dan menggambarkan mengenai suatu gejala yang ada, yaitu keadaan gejala menurut apa adanya pada saat penelitian dilakukan. Dengan menggunakan pendekatan kualitatif, peneliti harus berinteraksi secara langsung dengan obyek penelitian dengan tujuan untuk mendapatkan informasi yang akurat, apa adanya, melalui suatu proses wawancara sehingga bisa mencapai target yang dibutuhkan dalam penelitian. Penelitian ini dilakukan di Kantor DPRD Kota Palangka Raya sebagai lokus dari fenomena yang menjadi tema penelitian. Selain itu pemilihan lokasi penelitian didasarkan pada kemudahan akses peneliti untuk mendapatkan data.

\section{HASIL DAN PEMBAHASAN}

Dewan Perwakilan Rakyat Daerah (DPRD) Kota Palangka Raya adalah partner bagi Kepala Daerah di dalam menjalankan tugasnya selaku aparat Pemerintah Daerah, sebagaimana dijelaskan dalam Tata Tertib DPRD Kota Palangka Raya No. 0I Tahun 2014 Pasal 3 tersebut. Konstruksi yang demikian menjamin upaya mendorong pemberdayaan masyarakat Kabupaten Kota Palangka Raya, pengembangan prakarsan dan kreativitas, meningkatkan partisipasi masyarakat, serta mengembangkan peran dan fungsi DPRD. Seperti tersurat dalam UU No. 23/20I4 tentang Pemerintah Daerah bahwa, DPRD sebagai badan pembentukan peraturan daerah yang berkedudukan sejajar dan menjadi mitra Pemerintah Daerah. Selanjutnya dalam pasal I sub c disebutkan bahwa Dewan Perwakilan Rakyat Daerah adalah Badan Legislatif Daerah (Pembuat Peraturan Daerah). 
Dengan demikian terdapat pembagian tugas yang jelas antara Kepala Daerah dengan DPRD Kota Palangka Raya dalam penyelengaraan Pemerintahan Daerah Kota Palangka Raya, yaitu Kepala Daerah Kota Palangka Raya memimpin bidang Eksekutif dan DPRD Kota Palangka Raya bergerak dalam bidang Legislatif. Sebagai Badan Legislatif Daerah, maka peran utama dari DPRD Kota Palangka Raya adalah menetapkan kebijaksanaan daerah, yang diwujudkan dalam Peraturan DPRD Kota Palangka Raya Nomor I Tahun 2014 tentang Tata Tertib DPRD Kota Palangka Raya Masa Jabatan 2014-2019. Di samping itu DPRD Kota Palangka Raya mempunyai fungsi untuk mengadakan atau melaksanakan pengawasan terhadap pelaksanaan kebijakan daerah yang dilakukan oleh Kepala Daerah Kota Palangka Raya, sebagaimana dijelaskan dalam Tata Tertib DPRD Kota Palangka Raya, jadi fungsi DPRD Kota Palangka Raya adalah:
a. Legislas;
b. Anggaran; dan
c. Pengawasan

Selanjutnya terkait dengan kinerja DPRD Kota Palangka Raya adalah menentukan kebijakan dan membuat Peraturan Undang-undang (peraturan daerah). Pelaksanaan fungsi atau kinerja DPRD Kota Palangka Raya tersebut melalui beberapa proses mulai dari penyusunan rancangan peraturan daerah, pembahasan rancangan peraturan daerah sampai ditetapkan menjadi Peraturan Daerah. Selanjutnya dalam penelitian ini, penulis akan menggambarkan pelaksanaan fungsi legislasi DPRD Kota Palangka Raya sekaligus mekanisme penyusunan peraturan daerah, hubungan DPRD dengan eksekutif dalam penyusunan Peraturan daerah dan aktor yang terlibat dalam pembuatan peraturan daerah. Namun sebelumnya disampaikan terlebih dahulu mengenai kinerja DPRD Kota Palangka Raya terkait dengan rapat-rapat DPRD Kota Palangka Raya Periode 2014-2019 sebagai berikut:
I. Rapat

Dibawah ini akan disampaikan tabel terkait dengan jenis-jenis rapat DPRD Kota Palangka Raya periode 2014-2019 di tahun 2015 sd. 2017, sebagai berikut:

Tabel I.

Rapat Keputusan Tahun 2015,20I6,20I7 DPRD Kota Palangka Raya periode 2014-2019

\begin{tabular}{|c|c|c|}
\hline $\begin{array}{c}\text { Jenis } \\
\text { Kegiatan/rapat }\end{array}$ & $\begin{array}{c}\text { Tahun } \\
\text { Pelaksanaan }\end{array}$ & Jumlah \\
\hline Rapat Keputusan & 2015 & 12 \\
\hline Rapat Keputusan & 2016 & 17 \\
\hline Rapat Keputusan & 2017 & 7 \\
\hline
\end{tabular}

Dari tabel diatas dapat dilihat bahwa rapat keputusan DPRD Kota Palangka Raya pada 3 tahun berjalan dengan jumlah 36 rapat keputusan, akan tetapi rapat keputusan tersebut yang banyak dihasilkan pada tahun 2016 dengan jumlah 17 dan yang paling sedikit di tahun 2017 dengan jumlah 7 rapat keputusan. Anggota DPRD Kota Palangka Raya pada tahun 2017 lebih banyak kegiatan riset, maka dari itu pada Tahun 2017 hanya dihasilkan 7 rapat keputusan.

Tabel 2.

Rapat BANMUS DPRD Kota Palangka Raya periode 2014-2019

\begin{tabular}{|c|c|c|}
\hline $\begin{array}{c}\text { Jenis } \\
\text { Kegiatan/rapat }\end{array}$ & $\begin{array}{c}\text { Tahun } \\
\text { Pelaksanaan }\end{array}$ & Jumlah \\
\hline Rapat BANMUS & 2015 & 5 \\
\hline Rapat BANMUS & 2016 & 2 \\
\hline Rapat BANMUS & 2017 & 1 \\
\hline
\end{tabular}

Dari tabel di atas dapat dilihat bahwa Rapat Badan Musyawarah yang dilakukan oleh DPRD Kota Palangka Raya pada Tahun 2014-2019 dengan jumlah 8 kali Rapat BANMUS, pada Tahun 2015 terdapat 5 rapat dan Tahun 2016 terdapat 2 rapat. Pada tahun 2017 hanya ada I rapat yang dibuat oleh DPRD dalam hal ini Rapat Badan Musyawarah, hal tersebut dikarenakan pada tahun tersebut Aanggota DPRD Kota Palangka Raya 
dalam hal BANMUS tidak menjadwalkan dan lebih banyak riset. Hal tersebut juga mengalami penurunan rapat yang dilakukuan oleh badan munsyawarah, ini menunjukan bahwa BANMUS DPRD Kota Palangka Raya hanya menyesuaikan dengan tugas yang telah ditetapkan dalam Tata Tertib dan jadwal tersebut.

Selanjutnya berkaitan dengan rapat yang dilakukan oleh Anggota DPRD Kota Palangka Raya khususnya anggota Badan Musyawarah (BANMUS), dalam melakukan rapat tersebut terkadang semua anggota BANMUS hadir untuk melakukan rapat dan terkadang pula sebagian saja yang hadir untuk mengikuti rapat yang dilakukan oleh anggota BANMUS tersebut.

Tabel 3.

Rapat BPPD DPRD Kota Palangka Raya periode 2014-2019

\begin{tabular}{|c|c|c|}
\hline $\begin{array}{c}\text { Jenis } \\
\text { Kegiatan/rapat }\end{array}$ & $\begin{array}{c}\text { Tahun } \\
\text { Pelaksanaan }\end{array}$ & Jumlah \\
\hline Rapat BANMUS & 2015 & 12 \\
\hline Rapat BANMUS & 2016 & 15 \\
\hline Rapat BANMUS & 2017 & 5 \\
\hline
\end{tabular}

Dari tabel di atas dapat dilihat bahwa Rapat BPPD DPRD Kota Palangka Raya sebanyak 32, rapat tersebut dilakukan paling banyak pada tahun 2016 dengan jumlah 15 kali rapat, sedangkan pada tahun 2017 hanya ada 5 kali rapat yang dilakukan, sesuai dengan Perda Kota Palangka Raya terdapat 17 Perda yang disahkan pada Tahun 2015.. Hal Ini menunjukan adanya kinerja yang cukup tinggi, dimana antara rapat BPPD tahun 2016 dengan Perda tahun 2016 jumlahnya hanya berselisih 2 saja. Maka dapat dikatakan bahwa kinerja DPRD Kota Palangka Raya dalam dalam hal ini. Anggota BPPD cenderung menjalankan fungsinya dengan baik.

Selanjutnya berkaitan dengan rapat yang dilakukan oleh Anggota DPRD Kota Palangka Raya khususnya anggota Badan Pembentukan Peraturan Daerah (BPPD), dalam melakukan rapat tersebut semua anggota BPPD diwajibkan hadir untuk melakukan rapat tersebut.

2. Pembuatan Peraturan Daerah

Mekanisme Penyusunan Peraturan Daerah Kota Palangka Raya diawali dari asal Perda tersebut berawal. Sebagaimana lazimnya produk hukum berupa Peraturan Daerah, ada 2 kemungkinan tentang usulan Perda. Yang pertama, rancangan peraturan daerah (raperda) berasal dari usulan pihak Pemerintah Daerah Kota Palangka Raya, dalam hal ini adalah Kepala Daerah Kota Palangka Raya, dimana hal ini diatur dalam Undang-undang Nomor 23 Tahun 2014 Pasal 25 Huruf b yang mengatur mengenai tugas dan wewenang Kepala Daerah yaitu “Mengajukan Rancangan Perda”.

Yang kedua, rancangan Perda berasal dari pihak DPRD Kota Palangka Raya. Hal ini diatur dalam Tata Tertib DPRD Kota Palangka Raya No. 01 Tahun 2014 dan diperkuat dengan Undang-undang No. 23 Tahun 2014 yang menyatakan bahwa DPRD mempuntai tugas dan wewenang membentuk Perda yang dibahas dengan Kepala Daerah untuk mendapat persetujuan bersama.

Terdapat serangkaian langkah utama yang perlu dilakukan agar Perda Kota Palangka Raya dapat dirumuskan dengan baik dan pelaksanaanya dapat efektif. Adapun langkah atau tahapan dalam penyusunan Perda meliputi tahan perencanaan raperda, tahap perancangan raperda, tahap pengajuan raperda, tahap penyebarluasan raperda, tahap pembahasan raperda, tahap penetapan raperda, tahap pengundangan dan tahap penyebarluasan Perda. Adpun RANPERDA yang ditetapkan sebagai berikut : 
Tabel 4.

Raperda yang ditetaokan menjadi Perda Kota Palangkaraya Tahun 20I5-2017

\begin{tabular}{|c|c|c|c|c|}
\hline No & \begin{tabular}{|l|} 
Tahun \\
\end{tabular} & Judul & Usulan/Inisiatif & Status \\
\hline 1 & 2015 & $\begin{array}{l}\text { Penyelenggaraan Pendidikan } \\
\text { non Formal }\end{array}$ & $\begin{array}{l}\text { DPRD Kota } \\
\text { Palangka Raya }\end{array}$ & $\begin{array}{c}\text { Sudah } \\
\text { dibahas dan } \\
\text { ditetapkan }\end{array}$ \\
\hline 2 & 2015 & \begin{tabular}{l|} 
Tanggung Jawab Sosial \\
Perusanaan Teradap \\
Masyarakat dan Pemerintah \\
Kota Palangka Raya
\end{tabular} & $\begin{array}{l}\text { DPRD Kota } \\
\text { Palangka Raya }\end{array}$ & $\begin{array}{c}\text { Sudah } \\
\text { dibahas dan } \\
\text { ditetapkan }\end{array}$ \\
\hline 3 & 2015 & $\begin{array}{l}\text { Tata Cara Penyelesaian } \\
\text { Kerugian Negara di } \\
\text { Lingkungan Pemerintah Kota } \\
\text { Palangka Raya }\end{array}$ & $\begin{array}{l}\text { Pemko Palangka } \\
\text { Raya }\end{array}$ & $\begin{array}{c}\text { Sudah } \\
\text { dibahas dan } \\
\text { ditetapkan }\end{array}$ \\
\hline 4 & 2015 & $\begin{array}{l}\text { Penyelenggaraan Administrasi } \\
\text { Kependudukan Kota Palangka } \\
\text { Raya }\end{array}$ & $\begin{array}{l}\text { Pemko Palangka } \\
\text { Raya }\end{array}$ & $\begin{array}{c}\text { Sudah } \\
\text { dibahas dan } \\
\text { ditetapkan }\end{array}$ \\
\hline 5 & 2015 & $\begin{array}{l}\text { Penyelenggaraan Kersipan } \\
\text { Kota Palangka Raya }\end{array}$ & $\begin{array}{c}\text { Pemko Palangka } \\
\text { Raya }\end{array}$ & $\begin{array}{l}\text { Sudah } \\
\text { dibahas dan } \\
\text { ditetapkan }\end{array}$ \\
\hline 6 & 2015 & \begin{tabular}{|l|} 
Retribusi Pelayanan \\
Pemakaman dan Pengabuan \\
Mayat di Kota Palangka Raya
\end{tabular} & $\begin{array}{l}\text { Pemko Palangka } \\
\text { Raya }\end{array}$ & $\begin{array}{l}\text { Sudah } \\
\text { dibahas dan } \\
\text { ditetapkan }\end{array}$ \\
\hline 7 & 2015 & $\begin{array}{l}\text { an Perda No } 4 \\
2012 \text { Tentang Pajak }\end{array}$ & $\begin{array}{l}\text { Pemko Palangka } \\
\text { Raya }\end{array}$ & $\begin{array}{c}\text { Sudah } \\
\text { dibahas dan } \\
\text { ditetapkan }\end{array}$ \\
\hline 8 & 2015 & $\begin{array}{l}\text { an Perda No } 5 \\
\text { 2012 Tentang Pajak } \\
\text { gan Jalan }\end{array}$ & $\begin{array}{l}\text { Pemko Palangka } \\
\text { Raya }\end{array}$ & $\begin{array}{c}\text { Sudah } \\
\text { dibahas dan }\end{array}$ \\
\hline & & & & altetapkan \\
\hline 9 & 2015 & $\begin{array}{l}\text { Penyelenggaraan Jaminan } \\
\text { Kesehatan Daerah Program } \\
\text { Penerima Bantuan luran APBD } \\
\text { Berupa Palangka Raya Sehat }\end{array}$ & $\begin{array}{l}\text { Pemko Palangka } \\
\text { Raya }\end{array}$ & $\begin{array}{c}\text { Sudah } \\
\text { dibahas dan } \\
\text { ditetapkan }\end{array}$ \\
\hline 10 & 2015 & $\begin{array}{l}\text { Pertanggungjaw } \\
\text { Pelaksanaan AP } \\
\text { Palangka Raya } \\
\end{array}$ & $\begin{array}{l}\text { Pemko Palangka } \\
\text { Raya }\end{array}$ & $\begin{array}{c}\text { Sudah } \\
\text { dibahas dan } \\
\text { ditetapkan } \\
\end{array}$ \\
\hline 11 & 2015 & $\begin{array}{l}\text { Perubahan APBD Kota } \\
\text { Palangka Raya TA } 2015\end{array}$ & $\begin{array}{l}\text { Pemko Palangka } \\
\text { Raya }\end{array}$ & $\begin{array}{c}\text { Sudah } \\
\text { dibahas dan } \\
\text { ditetapkan }\end{array}$ \\
\hline 12 & 2015 & $\begin{array}{l}\text { APBD Kota Palangka Raya } \\
\text { Tahun Anggaran } 2016\end{array}$ & $\begin{array}{l}\text { Pemko Palangka } \\
\text { Raya }\end{array}$ & $\begin{array}{c}\text { Sudah } \\
\text { dibahas dan } \\
\text { ditetapkan }\end{array}$ \\
\hline 13 & 2016 & $\begin{array}{l}\text { Penanggulangan Be } \\
\text { Alam dan Sosial }\end{array}$ & $\begin{array}{r}\text { DPRD K } \\
\text { Palangka }\end{array}$ & $\begin{array}{c}\text { Sudah } \\
\text { dibahas dan } \\
\text { ditetapkan }\end{array}$ \\
\hline 14 & 2016 & $\begin{array}{l}\text { Penyelenggaraan Pro } \\
\text { dan Keuangan DPRD } \\
\text { Palangka Raya } \\
\end{array}$ & ta & $\begin{array}{c}\text { Sudah } \\
\text { dibahas dan } \\
\text { ditetapkan }\end{array}$ \\
\hline 15 & 2016 & $\begin{array}{l}\text { In dan } \\
\text { angan Bahan } \\
\text { Makanan }\end{array}$ & $\begin{array}{l}\text { DPRD Kota } \\
\text { Palangka Raya }\end{array}$ & $\begin{array}{c}\text { Sudah } \\
\text { dibahas dan } \\
\text { ditetapkan }\end{array}$ \\
\hline 16 & 2016 & $\begin{array}{l}\text { Damang Kepala Ada } \\
\text { Palangka Raya }\end{array}$ & $\begin{array}{l}\text { Pemko Palangka } \\
\text { Raya }\end{array}$ & $\begin{array}{c}\text { Sudah } \\
\text { dibahas dan } \\
\text { ditetapkan }\end{array}$ \\
\hline 17 & 2016 & Pajak Daerah & $\begin{array}{l}\text { Pemko Palangka } \\
\text { Raya }\end{array}$ & $\begin{array}{c}\text { Sudah } \\
\text { dibahas dan } \\
\text { ditetapkan }\end{array}$ \\
\hline 18 & 2016 & Retribusi Daerah & $\begin{array}{l}\text { Pemko Palangka } \\
\text { Raya }\end{array}$ & $\begin{array}{c}\text { Sudah } \\
\text { dibahas dan } \\
\text { ditetapkan }\end{array}$ \\
\hline 19 & 2016 & $\begin{array}{l}\text { Pengelolaan Kebersihan } \\
\text { Lingkungan dan Pertamanan }\end{array}$ & $\begin{array}{l}\text { Pemko Palangka } \\
\text { Raya }\end{array}$ & $\begin{array}{c}\text { Sudah } \\
\text { dibahas dan } \\
\text { ditetapkan }\end{array}$ \\
\hline 20 & 2016 & Bangunan Gedung & $\begin{array}{l}\text { Pemko Palangka } \\
\text { Raya }\end{array}$ & $\begin{array}{c}\text { Sudah } \\
\text { dibahas dan } \\
\text { ditetapkan }\end{array}$ \\
\hline 21 & 2016 & Kepari & $\begin{array}{l}\text { Pemko Palangka } \\
\text { Raya }\end{array}$ & $\begin{array}{c}\text { Sudah } \\
\text { dibahas dan } \\
\text { ditetapkan }\end{array}$ \\
\hline 22 & 2016 & $\begin{array}{l}\text { Rencana Induk Pembangunan } \\
\text { Kepariwisataan Kota Palangka } \\
\text { Raya }\end{array}$ & $\begin{array}{l}\text { Pemko Palangka } \\
\text { Raya }\end{array}$ & $\begin{array}{c}\text { Sudah } \\
\text { dibahas dan } \\
\text { ditetapkan }\end{array}$ \\
\hline 23 & 2016 & $\begin{array}{l}\text { Penyelenggaraan Pelayanan } \\
\text { Terpadu Satu Pintu Kota } \\
\text { Palangka Raya }\end{array}$ & $\begin{array}{l}\text { Pemko Palangka } \\
\text { Raya }\end{array}$ & $\begin{array}{c}\text { Sudah } \\
\text { dibahas dan } \\
\text { ditetapkan }\end{array}$ \\
\hline 24 & 2016 & $\begin{array}{l}\text { Perubahan Rencana } \\
\text { Pembangunan Jangka } \\
\text { Menengah Daerah Kota }\end{array}$ & $\begin{array}{l}\text { Pemko Palangka } \\
\text { Raya }\end{array}$ & $\begin{array}{c}\text { Sudah } \\
\text { dibahas dan } \\
\text { ditetapkan }\end{array}$ \\
\hline
\end{tabular}

\begin{tabular}{|c|c|c|c|c|}
\hline 25 & 2016 & $\begin{array}{l}\text { Dana Cadangan Pemilihan } \\
\text { Kepala Daerah }\end{array}$ & $\begin{array}{l}\text { Pemko Palangka } \\
\text { Raya }\end{array}$ & $\begin{array}{l}\text { Sudah } \\
\text { dibahas dan } \\
\text { ditetapkan }\end{array}$ \\
\hline 26 & 2016 & $\begin{array}{l}\text { Bank Perkreditan Rakyat } \\
\text { (BPR) }\end{array}$ & $\begin{array}{l}\text { Pemko Palangka } \\
\text { Raya }\end{array}$ & $\begin{array}{c}\text { Sudah } \\
\text { dibahas dan } \\
\text { ditetapkan }\end{array}$ \\
\hline 27 & 2016 & $\begin{array}{l}\text { Pertanggungjawaban } \\
\text { Pelaksanaan APBD Kota } \\
\text { Palangka Raya TA } 2015\end{array}$ & $\begin{array}{l}\text { Pemko Palangka } \\
\text { Raya }\end{array}$ & \begin{tabular}{|c|} 
Sudah \\
dibahas dan \\
ditetapkan \\
\end{tabular} \\
\hline 28 & 2016 & $\begin{array}{l}\text { Perubahan APBD Kota } \\
\text { Palangka Raya TA } 2016\end{array}$ & $\begin{array}{l}\text { Pemko Palangka } \\
\text { Raya }\end{array}$ & \begin{tabular}{|c|} 
Sudah \\
dibahas dan \\
ditetapkan \\
\end{tabular} \\
\hline 29 & 2016 & $\begin{array}{l}\text { APBD Kota Palangka Raya } \\
\text { Tahun Anggaran } 2017\end{array}$ & $\begin{array}{l}\text { Pemko Palangka } \\
\text { Raya }\end{array}$ & $\begin{array}{c}\text { Sudah } \\
\text { dibahas dan } \\
\text { ditetapkan }\end{array}$ \\
\hline 30 & 2017 & $\begin{array}{l}\text { Penanganan Penyalahgunaan } \\
\text { Psikotropika, Narkotika dan Zat } \\
\text { Aditif }\end{array}$ & $\begin{array}{l}\text { DPRD Kota } \\
\text { Palangka Raya }\end{array}$ & $\begin{array}{c}\text { Sudah } \\
\text { dibahas dan } \\
\text { ditetapkan }\end{array}$ \\
\hline 31 & 2017 & $\begin{array}{l}\text { Penyelenggaraan Bantuan } \\
\text { Hukum Bagi Masyarakat Kota } \\
\text { Palangka Raya }\end{array}$ & $\begin{array}{l}\text { DPRD Kota } \\
\text { Palangka Raya }\end{array}$ & $\begin{array}{c}\text { Sudah } \\
\text { dibahas dan } \\
\text { ditetapkan }\end{array}$ \\
\hline 32 & 2017 & $\begin{array}{l}\text { Pengaturan Rumah Potong } \\
\text { Hewan }\end{array}$ & $\begin{array}{l}\text { DPRD Kota } \\
\text { Palangka Raya }\end{array}$ & $\begin{array}{c}\text { Sudah } \\
\text { dibahas dan } \\
\text { ditetapkan }\end{array}$ \\
\hline 33 & 2017 & $\begin{array}{l}\text { Pengelolaan Laboratorium } \\
\text { Pengujian Mutu Konstruksi }\end{array}$ & $\begin{array}{l}\text { Pemko Palangka } \\
\text { Raya }\end{array}$ & $\begin{array}{c}\text { Sudah } \\
\text { dibahas dan } \\
\text { ditetapkan } \\
\end{array}$ \\
\hline 34 & 2017 & $\begin{array}{l}\text { Pertanggungjawaban } \\
\text { Pelaksanaan APBD Kota } \\
\text { Palangka Raya TA } 2016 \\
\end{array}$ & $\begin{array}{l}\text { Pemko Palangka } \\
\text { Raya }\end{array}$ & \begin{tabular}{|c|} 
Sudah \\
dibahas dan \\
ditetapkan \\
\end{tabular} \\
\hline 35 & 2017 & $\begin{array}{l}\text { Perubahan APBD Kota } \\
\text { Palangka Raya TA } 2017\end{array}$ & $\begin{array}{l}\text { Pemko Palangka } \\
\text { Raya }\end{array}$ & $\begin{array}{c}\text { Sudah } \\
\text { dibahas dan } \\
\text { ditetapkan } \\
\end{array}$ \\
\hline 36 & 2017 & $\begin{array}{l}\text { APBD Kota Palangka Raya } \\
\text { Tahun Anggaran } 2018\end{array}$ & $\begin{array}{l}\text { Pemko Palangka } \\
\text { Raya }\end{array}$ & $\begin{array}{c}\text { Sudah } \\
\text { dibahas dan } \\
\text { ditetapkan }\end{array}$ \\
\hline
\end{tabular}

Dari tabel di atas dapat dilihat bahwa Ranperda yang telah ditetapkan menjadi Perda Kota Palangka Raya Tahun 2015-2017 sebanyak 36 Perda yang telah ditetapkan tersebut sudah telah disetujui bersama antara DPRD dan Walikota Kota Palangka Raya.

3. Faktor Kendala yang Mempengaruhi Dalam Penetapan Perda

Hubungan Pemerintah Daerah dan DPRD Kota Palangka Raya dalam hal penyusunan peraturan daerah dimanifestasikan atau di wujudkan dengan kegiatan interaksi dan negosiasi. Hal ini sangat dibutuhkan karena pada aspek berpemerintahan sangat dibutuhkan keseimbangan antara Pemerintah Daerah dan DPRD dalam mewujudkan harapan rakyat yang sesungguhnya.

a. Aktor Yang Terlibat

Proses penyusunan Peraturan Daerah Kota Palangka Raya selalu melibatkan aktor-aktor yang berhubungan langsung dengan peraturan daerah yang akan dihasilkan. Aktor-aktor yang terlibat tersebut yaitu DPRD, Pemerintah Kota Palangka Raya, Akademisi dan masyarakat. Dari DPRD aktor yang terlibat yakni Badan Pembentukan Peraturan Daerah 
dan untuk Pemkab diwakili oleh Bagian Hukum dan leading sector. Sedangkan dari pihak masyarakat 55 diwakili oleh beberapa perwakilan yang terkait langsung dengan peraturan daerah yang akan dibahas

b. Keterlibatan masyarakat

Pasal I39 ayat (I) menyebutkan bahwa "masyarakat berhak memberikan masukan secara lisan dan tertulis dalam rangka penyiapan atau pembahasan rancangan Perda. Penting untuk menjamin partisipasi masyarakat dalam penyusunan peraturan daerah. Partisipasi masyarakat merupakan unsur penting yang nantinya akan terlibat langsung dengan pelaksanaan peraturan daerah ketika sudah diundangkan dan dinyatakan berlaku.

Selain masyarakat yang berkepentingan, unsur dari masyarakat yang juga dilibatkan yakni dari kalangan kampus dan akademisi untuk memberikan masukan-masukan terkait dengan peraturan daerah baik teknis maupun substansi dari peraturan daerah tersebut.

Penulis dapat mencatat ada beberapa hambatan atau faktor-faktor yang mempengaruhi kinerja oleh DPRD Kota Palangka Raya di antaranya :

a. Sumber Daya Manusia

Bahwa peran DPRD Kota Palangka Raya dalam penyusunan peraturan daerah masih sangat rendah bila dibandingkan dengan pihak eksekutif. Rendahnya insiatif DPRD Kota Palangka Raya disebabkan terutama Sumber Daya Manusia (SDM) yang ada di Anggota DPRD dibandingkan dengan SDM yang ada di dalam Anggota Eksekutif. Selain itu, walaupun sebagian Anggota DPRD tingkat pendidikannya Sarjana, namun tidak sesuai dengan besic keilmuan yang selayaknya bisa dan paham dalam mengaktualisasi fungsi DPRD.
Sedangkan dari pihak eksekutif memiliki aturan baku tentang jenjang pendidikan mulai dari rekrutmen sampai pada promosi, sehingga hanya SDM tertentu yang bisa menduduki jabatan sebagai penentu kebijakan. Berbeda yang terjadi di DPRD pelaksanaan rekrutmen anggoota DPRD ditentukan oleh jumlah kursi yang diperoleh dalam pemilu, selain itu kadang disiplin ilmu belum sesuai dengan tugas yang akan dijalankan.

Hal tersebut juga berdasarkan atas Tingkat Pendidikan DPRD Kota Palangka Raya Periode 2014-2019, dengan tingkat pendidikan Pascasarjana 2 orang, Sarjana 19 orang dan SLTA 9 orang. Dengan melihat tingkat pendidikan tersebut disimpulkan bahwa ternyata DPRD Kota Palangka Raya masih terdapat yang berpendidikan SMA. Latar belakang pendidikan berpengaruh terhadap kinerja DPRD Kota Palangka Raya tersebut, memang ada 2 anggota DPRD yang sudah berpendidikan S2 dan 19 orang yang SI, akan tetapi dari tingkat pendidikan tersebut kebanyakan tidak sesuai dengan basic yang dimiliki Anggota DPRD Kota Palangka Raya dan tidak sesuai pula dengan jabatan dan/atau kinerjanya tersebut.

b. Data atau Informasi

Ada beberapa keuntungan dari ketersediaan data/informasi, antara lain adalah: bertambahnya alternatif-alternatif dan pendekatan-pendekatan baru guna pemecahan masalah-masalah dan guna mengurangi timbulnya masalahmasalah serupa di masa mendatang, semakin lebarnya landasan ilmu pengetahuan guna keperluan pemecahan masalah-masalah dan meningkatkan ketepatan pengambilan keputusan seluruh sektor dan seluruh kegiatan. 
Karena itu, informasi yang bernilai tinggi akan mendukung pengambilan keputusan yang tepat. Informasi yang ada selama ini berdasarkan pengamatan di lapangan dirasakan belum relevan dan belum memiliki validitas yang tinggi terhadap permasalahan yang dihadapi, untuk itu diperlukan kerja keras dari anggota Dewan untuk aktif mencari sumber informasi lain yang lebih tepat dan akurat.

Berdasarkan keterangan-keterangan yang didapatkan dapat diinterpretasikan bahwa, informasi yang ada belum dimanfaatkan secara optimal oleh anggota DPRD Kota Palangka Raya dalam mengambil suatu kebijakan, diantaranya karena informasi yang ada belum tentu akurat, tidak sesuai dengan kenyataan yang ada sehingga belum dapat digunakan sebagai dasar untuk pengambilan suatu keputusan. Disini diperlukan adanya sarana pelayanan informasi yang akan menyediakan berbagai informasi yang memadai dan mudah diperoleh, karena tanpa informasi yang memadai dan mudah diperoleh maka para anggota legislatif akan mengalami kesulitan dalam membahas berbagai masalah dengan mitra kerjanya.

c. Pengalaman

Seorang Anggota DPRD Kota Palangka Raya disebut berpengalaman jika ia senantiasa menghasilkan karya/ pandangan baru dalam bidangnya, bersikap adaptif dan inovatif, senantiasa mengikuti dan menyesuaikan diri dengan perkembangan ilmu pengetahuan dan teknologi, selalu merubah strategi pendekatannya dalam menangani masalah pembangunan, dan senantiasa meningkatkan ketrampilan profesionalnya sebagai anggota DPRD Kota Palangka Raya.
Diketahui bahwa, pengalaman Anggota DPRD Kota Palangka Raya yang belum pernah duduk dalam lembaga legislatif sebelumnya berpengaruh terhadap pelaksanaan tugas pokok dan fungsi yang diembannya saat ini sebagai wakil rakyat, paling tidak dia dapat mengetahui kekurangan-kekurangan yang ada pada dirinya sebelumnya untuk kemudian berusaha memperbaikinya dengan langkahlangkah yang lebih tepat. Ada beberapa anggota DPRD Kota Palangka Raya yang sebelumnya sudah perna menduduki jabatan selaku Anggota DPRD. Namun justru lebih banyak jumlah anggota yang belum pernah sama sekali menjadi Anggota DPRD.

\section{KESIMPULAN}

Kinerja Dewan Perwakilan Rakyat Daerah (DPRD) Kota Palangka Raya dalam melaksanakan kekuasaan legislasi bersama Pemerintah Kota Palangka Raya dapat dikatakan cukup baik. Pada periode tahun 2015 sampai dengan tahun 2017 telah membahas dan menetapkan 36 Peraturan Daerah. Akan tetapi apabila ditinjau dari inisiasi usulan maka dapat dikatakan kurang memuaskan, karena hanya 9 Peraturan daerah aja yang merupakan inisiatif DPRD Kota Palangka Raya.

Faktor-faktor yang mempengaruhi kinerja DPRD Kota Palangka Raya dalam menetapkan Peraturan Daerah adalah : Sumber Daya Manusia, Data dan Inforasi, serta Pengalaman. Keadaan Sumber Daya Manusia yang ratarata berpendidikan Sarjana ke atas (2I dari 30 orang) sebenarnya merupakan factor pendukung kinerja. Menilik bahwa basic pendidikan yang tidak sejalan dan pengalaman yang masih kurang turut menjadi kendala untuk mendukung kinerja legislasi anggota DPRD Kota Palangka Raya. 


\section{REFERENSI}

Beriansyah, Alva dan Mutiarin, Dyah. 2015. Analisis Hasil Reses DPRD dalam Penyusunan Dan Penetapan APBD Kabupaten Ogan Komering Ulu Selatan Tahun Anggaran 20/4. Journal of Governance and Public Policy Vol 2. No 2: June 2015 page. 389-4I5. Universitas Muhammadiyah Yogyakarta.

Evanty, Nukila dan Ghufron Nurul. 2014. Paham Peraturan Daerah Berspektif Hak Asasi Manusia. Rajawali Press.Jakarta.

Hasan, Amiek Soemarmi, Indarja. 2012. Tugas Dan Wewenang Dewan Perwakilan Rakyat Daerah (DPRD) Dalam Pelaksanaan Fungsi Anggaran Pendapatan Dan Belanja Daerah (APBD) Provinsi Jawa Tengah Periode 2009-20II. Diponegoro Law Review, Volume I, Nomor 4, Tahun 2012, http://ejournal-s I.undip.ac.id/index. php/dlr.

Huda, Ni'matul. 20I0. Problematika Pembatalan Peraturan Daerah. FH UII PRESS. Yogyakarta.

Ida, Zuraida. 2010. Teknik Penyusunan Peraturan Daerah. Sinar Grafika. Jakarta.

Indriani dan Baswir. 2003. Pengaruh pengetahuan dan RPPs terhadap peranan DPRD dalam pengawasan keuangan daerah. Jurnal Sosiohumanika (Vol.16/A) 2003 XVI(I).

Laksono Fajar Dan Subarjo. 2006. Kontroversi UndangUndang Tanpa Pengesahan Presiden. Balai Pustaka. Jakarta.

Manzilati, Asfi. 20II. Penguatan Fungsi Legislatif Dan Evaluasi Kinerja Bidang Penganggaran (Studi di DPRD Kota Batu). Journal of Indonesian Applied Economics. Vol. 5 No. 2 Oktober 2011, 252268.

Thaha, Idris . 2004. Demokrasi Religius. pemikiran Politik Nurcholis Madjid (alm) dan M. Amin Rais. Khazanah Pustaka Keilmuan. Jakarta.

Winarna, Jaka dan Murni, Sri. 2007. Pengaruh Personal Background, Political Background dan Pengetahuan Dewan tentang Anggaran terhadap Peran DPRD dalam Pengawasan Keuangan Daerah. Simposium Nasional Akuntansi X. Makasar.

Witono, Banu and, Baswir, Revrisond. 2003. Analisis pengaruh personal Background dan political culture terhadap peran DPRD dalam pengawasan keuangan daerah. thesis. 